\title{
Temporal and Spatial Change of Carbon Storage in Alara Forest Planning Unit
}

\author{
Mehmet SEKI ${ }^{1 *}$, Davut ATAR ${ }^{2}$ \\ ${ }^{1}$ Karabuk University, Faculty of Forestry, Karabuk, TURKEY \\ ${ }^{2}$ General Directorate of Forestry, Forest Modelling and Yield Office, Ankara, TURKEY \\ *Corresponding Author: mehmetseki@karabuk.edu.tr
}

Received Date: 04.04.2021

Accepted Date: 01.07.2021

\section{Abstract}

Aim of study: Land use and carbon stock changes of Alara Forest Planning Unit (FPU) between the years of 1997 and 2017 were investigated.

Area of study: Alara Forest Planning Unit (FPU) of Alanya Forest Enterprise (FE) within the boundaries of Antalya province, southwest Turkey.

Material and methods: Data obtained from the forest management plans for the periods of 1997-2006, 2008-2017 and 2018-2037 were used in the study. Biomass conversion and expansion factors (BCEF), root to shoot ratios $(\mathrm{R})$ and carbon factors $(\mathrm{CF})$ were used for carbon stock estimation.

Main results: Total forest area of the Alara FPU decreased from 7497 ha to 7344 ha, while total carbon stock of the forest lands increased by $12.7 \%$, from 1997 to 2017.

Highlights: Despite the reduction of total forest area from 1997 to 2017, carbon stocks of all biomass pools in forest ecosystem raised with the increase of productive forest lands and growing stock.

Keywords: Alara Forest Areas, Global Warming, Climate Change, Land Use, Carbon Stock Change

\section{Alara Orman İşletme Şefliği Karbon Stoğunun Zamansal ve \\ Konumsal Değişimi}

$\ddot{\mathbf{O}} \mathbf{z}$

Çalışmanın amacı: Bu çalışmada, Alara Orman İşletme Şefliği (OİŞ) için 1997 ve 2017 yılları arasında arazi kullanımının ve karbon stoğunun değişimi incelenmiştir.

Çalışma alanı: Bu çalışma, Antalya ili sınırları içerisinde yer alan Alanya Orman İşletme Müdürlüğü bünyesindeki Alara Orman İşletme Şefliği için gerçekleştirilmiş̧tir.

Materyal ve yöntem: 1997-2006, 2008-2017 ve 2018-2037 orman amenajman planlarından elde edilen veriler bu çalışmada kullanılmıştır. Çalışma alanı içerisindeki karbon stoğunun tahmini için biyokütle çevirme ve genişletme faktörleri (BCEF), kök/sak oranları (R) ve biyokütleyi karbona çevirme katsayıları (CF) kullanılmışıtır.

Temel sonuçlar: 1997 ve 2017 yılları arasında, Alara Oİş içerisinde yayılış gösteren ormanların alansal olarak büyüklükleri 7497 hektardan 7344 hektara düşmesine rağmen, ormanların depoladıkları karbon stoğunda \%12.7 lik bir artı̧̧ gözlenmiştir.

Araştırma vurgularl: 1997 y1lından 2017 yılına kadar geçen sürede toplam ormanlık alanlarda azalma olmasına karşın, verimli orman alanlarının ve dikili servetin artışı ile orantılı olarak orman ekosistemi içerisindeki tüm bileşenlerin depoladıkları karbon miktarlarında artış gözlenmiştir.

Anahtar Kelimeler: Küresel Isınma, İklim Değişikliği, Arazi Kullanımı, Karbon Stok Değişimi

\section{Introduction}

Global warming is defined as an increase in the temperature of the earth and thought to be provoked by the human activities such as industrialization, urbanization, deforestation, overuse of fossil fuels, etc. It's estimated that mean temperature of the earth, which is already $1{ }^{\circ} \mathrm{C}$ above pre-industrial levels, will increase by $1.5{ }^{\circ} \mathrm{C}$ between approximately the years of 2030 and 2052 (IPCC, 2018). Expected climate change could lead to uncertainty in natural systems, especially in forests. Climate is one of the most important factors affecting growth of the forest trees in mountain environments, and so expectation about climate change concerns the forest sustainability (Socha, 2008). Also, the respiration and photosynthesis rates of trees 
are expected to be affected in the coming years (Saxe et al., 2001). These concerns and warnings underline the importance of examination of natural balance between environment and climate, and hence investigation of relation between environment and climate change over time.

With increasing global awareness about climate change and its effects, carbon pools of the earth have received increasing importance in recent years. It seems possible to reduce, or at least delay the global warming by decreasing greenhouse gases emission and increasing carbon dioxide absorption from the atmosphere. Forests have been considered to be one of the most important carbon pools responsible for locking up carbon in the living biomass, soil, litter and dead wood (Vogt, 1991; Dixon et al., 1994). Moreover, forests have been managed over a long rotation ages, and this situation provides long-term carbon sequestration in the ecosystem. In epitome, forests are of great importance in storing large amount of carbon over the long-term.

The calculation and/or estimation of the forest carbon stock is an important issue to determine the role of forests in Earth's carbon cycle. Another issue as important as determination of the amount of carbon stored in forest ecosystems is to investigate the carbon stock change of forest biomass.
Especially, relationship between land use and carbon storage is one of the major point that is to be considered during decision making process of forest management. The objectives of this study were to investigate land use change, and hereby carbon stock change of forests of Alara FPU located in Antalya region.

\section{Material and Methods}

Study Area

This study was conducted in Alara Forest Planning Unit (FPU) of Alanya Forest Enterprise (FE) within the boundaries of Antalya province, southwest Turkey. Alara FPU was divided into 2 different FPUs in the year of 2019. Nevertheless, Alara FPU was examined as one unit (as before) for the last period. The study area has humid and semihumid Mediterranean climate, with annual average temperature of $18.8{ }^{\circ} \mathrm{C}$ and mean annual precipitation of $1058.3 \mathrm{~mm}$. Elevation of the studied area ranges from 0 to $785 \mathrm{~m}$ above sea level, with an average of $254 \mathrm{~m}$, and slope varies between 0 and $86 \%$. The total area of the studied FPU is 12683 ha, and forests cover approximately $58 \%$ of this FPU. The main species of the studied FPU is Brutian pine (Pinus brutia Ten.) which occupies over $95 \%$. The geographic location of the Alara FPU is given in Figure 1.

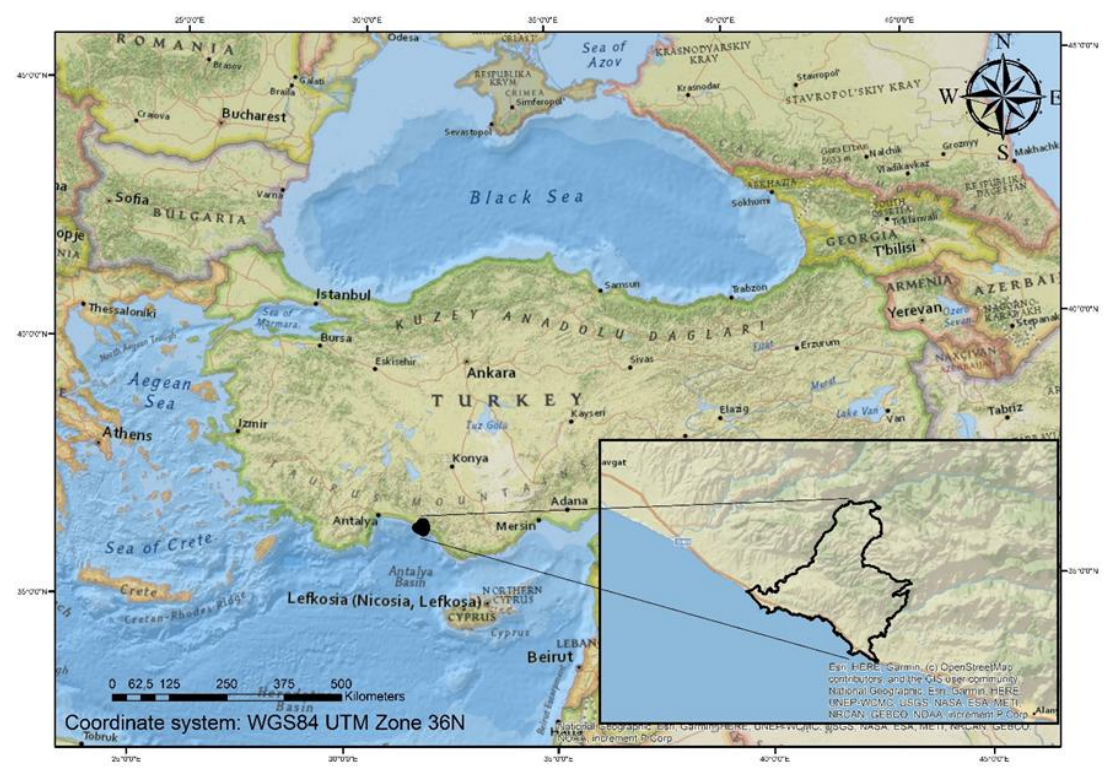

Figure 1. Geographic location of the study area 
Data

Forest inventories of the Alara FPU were carried out in the years of 1997, 2007 and 2017 , on account of forest management plans for the periods of 1997-2006, 2008-2017 and 2018-2037, respectively. Average growing stocks $\left(\mathrm{m}^{3} / \mathrm{ha}\right)$ of each stand type and total area of these stands were used for biomass and carbon stock calculations (GDF, 1997;
GDF, 2007; GDF, 2017a). Information on total area and growing stock by group of tree species (coniferous, deciduous and maquis) for the years of 1997, 2007 and 2017 is given in Table 1. Beside, Figure 2 illustrates the land use changes of the study area between 1997 and 2017. All geographic maps were produced by using ArcMap 10.6 Software provided by Esri (Esri, 2021).

Table 1. Descriptive information of the study area for the consecutive periods

\begin{tabular}{cccccccc}
\hline \multirow{2}{*}{$\begin{array}{c}\text { Stand } \\
\text { form }\end{array}$} & $\begin{array}{c}\text { Group of } \\
\text { Species }\end{array}$ & $\begin{array}{c}\text { Area } \\
\text { (ha) }\end{array}$ & $\begin{array}{c}\text { Growing } \\
\text { stock }\left(\mathrm{m}^{3}\right)\end{array}$ & $\begin{array}{c}\text { Area } \\
(\text { ha) }\end{array}$ & $\begin{array}{c}\text { Growing } \\
\text { stock }\left(\mathrm{m}^{3}\right)\end{array}$ & $\begin{array}{c}\text { Area } \\
(\text { ha })\end{array}$ & $\begin{array}{c}\text { Growing } \\
\text { stock }\left(\mathrm{m}^{3}\right)\end{array}$ \\
\hline \multirow{2}{*}{ Productive } & Coniferous & 5674 & 962815 & 6288 & 957801 & 6432 & 1108619 \\
& Deciduous & - & - & - & - & - & - \\
\hline \multirow{2}{*}{ Degraded } & Coniferous & 1790 & 13291 & 1352 & 10470 & 646 & 6230 \\
\cline { 3 - 8 } & Deciduous & 33 & 258 & 18 & 72 & - & - \\
\hline \multicolumn{2}{c}{ Maquis } & - & - & - & - & 266 & - \\
\hline \multicolumn{2}{c}{ Total } & 7497 & 976364 & 7658 & 968343 & 7344 & 1114849
\end{tabular}

Note: Productive means the forest stands having crown closure more than $10 \%$, while degraded means the forest stands having crown closure equal and less than $10 \%$

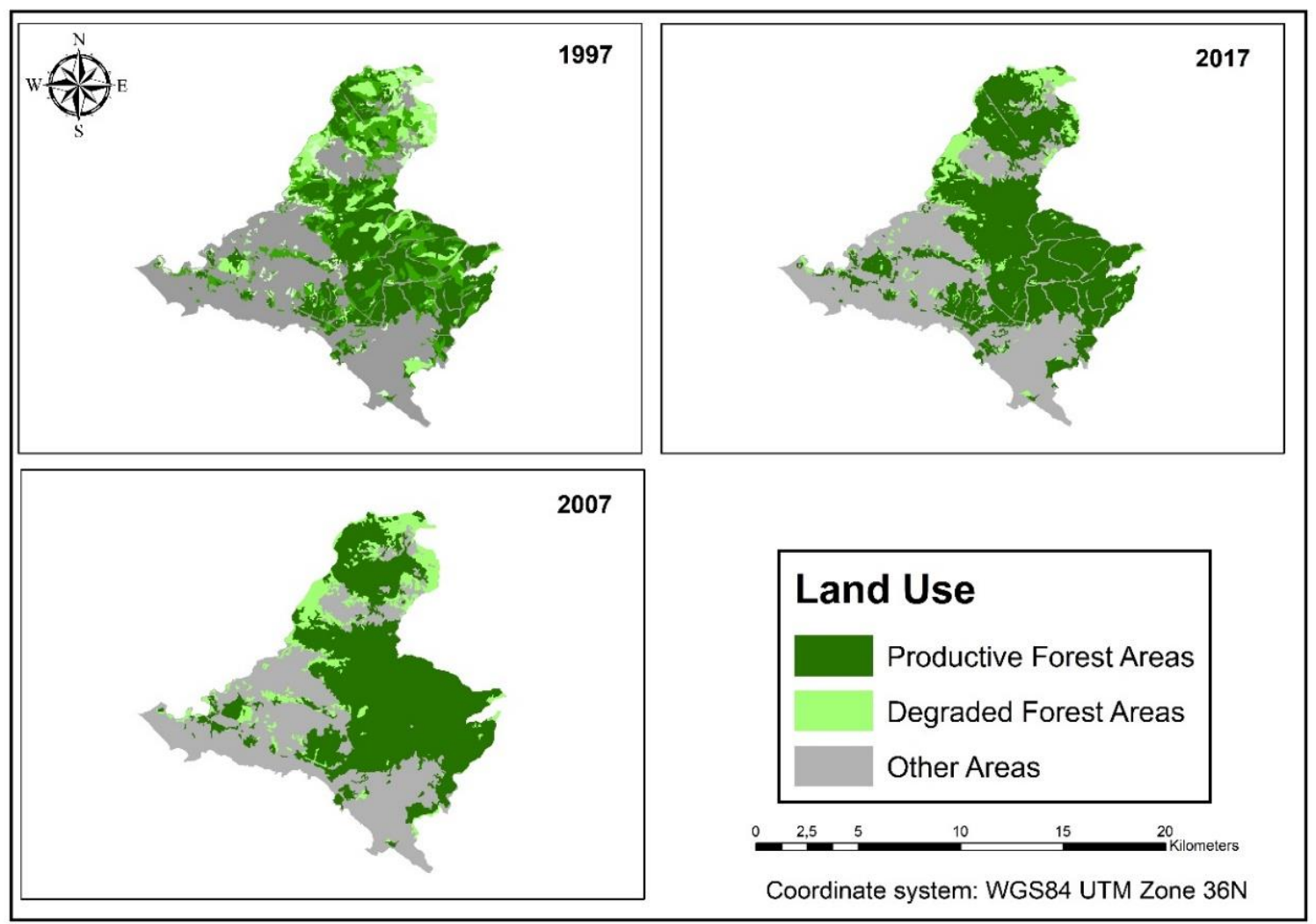

Figure 2. Land use change of the study area 
Biomass and Carbon Stock Calculations

First step for estimation of carbon stock in living tree biomass is to convert growing stock volume to stem biomass. For this conversion, stem volume of a tree is multiplied by basic wood density (WD). The stem biomass is multiplied by biomass expansion factor $(B E F)$ to calculate aboveground biomass $(A G B)$ value, while belowground biomass $(B G B)$ value is obtained by using root to shoot ratios $(R)$. Subsequently, carbon stock in the living tree biomass is calculated using carbon factor $(C F)$ (IPCC, 2003). If it's desired, $A G B$ can be estimated directly from the stem volume using biomass conversion and expansion factor $(B C E F)$, recommended in AFOLU (IPCC, 2006).

The formula for calculation of carbon stocks in living tree biomass is given as follows:
$C=V \times B C E F_{I} \times(1+R) \times C F$

where $V$ is the growing stock volume $\left(\mathrm{m}^{3}\right)$, BCEF $_{I}$ is the conversion and expansion factor $\left(M g / \mathrm{m}^{3}\right), R$ is the root to shoot ratio (dimensionless), $C F$ is the carbon factor, and $C$ is carbon stock $(M g)$.

There are various studies on determination of tree biomass in Turkey. Tolunay (2013) compiled the studies on this topic, and recalculated $B E F$ and $B C E F$ coefficients for Turkey. In this study, $B C E F$ coefficients for coniferous and deciduous tree species groups calculated in Tolunay (2013) were used (Table 2).

Table 2. $W D, B E F_{I}$ and $B C E F_{I}$ values given in Tolunay (2013)

\begin{tabular}{cccc}
\hline Group of species & $W D\left(M g / \mathrm{m}^{3}\right)$ & $B E F_{I}$ & $B C E F_{I}$ \\
\hline Coniferous & 0.446 & 1.212 & 0.541 \\
Deciduous & 0.541 & 1.310 & 0.709 \\
\hline
\end{tabular}

There is a deficiency in the number of studies investigating root biomass in Turkey. Therefore, $R$ values, and also $C F$ values given in AFOLU (IPCC, 2006) for temperate zone forests were used in this study (Table $3)$.

Table 3. $R$ and $C F$ values given in AFOLU (IPCC, 2006)

\begin{tabular}{cccc}
\hline Group of species & $A G B(M g / h a)$ & $R$ & $C F$ \\
\hline \multirow{3}{*}{ Coniferous } & $<50$ & 0.40 & \\
& $50-150$ & 0.29 & 0.51 \\
& $>150$ & 0.20 & \\
Deciduous & $<75$ & 0.46 & 0.48 \\
& $75-150$ & 0.23 & \\
\hline
\end{tabular}

Tolunay \& Çömez (2008) investigated the former studies on litter and soil carbon stocks, and calculated carbon densities per unit area. These values were used for determination of litter and soil carbon stocks of the study area (Table 4).

Table 4. Litter and soil carbon densities given in Tolunay and Çömez (2008)

\begin{tabular}{ccc}
\hline Group of species & Litter $(\mathrm{Mg} / \mathrm{ha})$ & Soil $(\mathrm{Mg} / \mathrm{ha})$ \\
\hline Coniferous & 7.46 & 75.56 \\
Deciduous & 3.75 & 84.82 \\
Maquis & 1.70 & 79.60 \\
\hline
\end{tabular}

Note: As there is not enough research on soil carbon of degraded forests in Turkey, the values given in Tolunay and Çömez (2008) are multiplied by 0.25 for degraded forests, as suggested in GDF (2017b). 
Although there is a deficiency in studies evaluating dead wood biomass, the assumption that $1 \%$ of the $A G B$ is equal to dead wood biomass is adopted (Tolunay, 2011; GDF, 2017b). The calculated dead wood biomass was multiplied by $C F$ value (0.47) given in FRA (2010) for dead wood carbon stock.

\section{Results}

Investigation of land use change between 1997 and 2017 showed that total area of the forest in the study field decreased from 7497 ha to 7344 ha. Despite the decrease in forest areas, there was a growing stock increase of $138485 \mathrm{~m}^{3}$ (14\%) between 1997 and 2017 (Table 1 and Figure 2). The main reason of this contrast is reduction in the rate of degraded forest areas, and hereby rises in accumulation of growing stock.

As seen from Table 5, above- and belowground, litter, soil, dead wood and total carbon stocks of the study area continuously increased from 1997 to 2017, while increase of carbon stocks in total living biomass is seen only between 2007 and 2017. This is the same trend with growing stock, as carbon stock in living tree biomass is highly correlated to tree volume. Total carbon stocks in the forest lands of the study area increased by $4.7 \%, 7.7 \%$ and $12.7 \%$ for the periods of 1997-2007, 2007-2017 and 19972017, respectively.

Table 5. Carbon stocks (Mg) in the forest lands of Alara in 1997, 2007 and 2017

\begin{tabular}{cccc}
\hline & 1997 & 2007 & 2017 \\
\cline { 2 - 4 } Above-ground & 269484.0 & 267205.5 & 307358.5 \\
& $31.4 \%$ & $29.7 \%$ & $31.8 \%$ \\
\hline \multirow{2}{*}{ Below-ground } & 78764.2 & 78304.8 & 88233.4 \\
& $9.2 \%$ & $8.7 \%$ & $9.1 \%$ \\
\hline \multirow{2}{*}{ Total living tree biomass } & 348248.2 & 345510.3 & 395591.9 \\
& $40.6 \%$ & $38.4 \%$ & $40.9 \%$ \\
\hline \multirow{2}{*}{ Litter } & 45687.8 & 49438.4 & 49638.8 \\
& $5.3 \%$ & $5.5 \%$ & $5.1 \%$ \\
\hline \multirow{2}{*}{ Soil } & 462151.0 & 501365.2 & 519551.0 \\
& $53.8 \%$ & $55.8 \%$ & 53.7 \\
\hline \multirow{2}{*}{ Dead wood } & 2483.8 & 2462.6 & 2833 \\
& $0.3 \%$ & $0.3 \%$ & $0.3 \%$ \\
\hline \multirow{2}{*}{ Total } & 858570.7 & 898776.5 & 967614.6 \\
& $100.0 \%$ & $100.0 \%$ & $100.0 \%$ \\
\hline
\end{tabular}

The contributions of carbon stock pools (above-ground, below-ground, litter, soil and dead wood) of forest ecosystem are given in Figure 3. As seen from the figure, forest soil is the major carbon pool of the forest ecosystems, with approximate percentages of $53.7-55.8 \%$. Beside, above-ground biomass of living trees in the forest area lock up approximately $29.7-31.8 \%$ of the total carbon stored in the forest ecosystem. Below-ground biomass, litter and dead wood have approximately $9 \%, 5 \%$ and $0.3 \%$ of the total carbon, respectively. The proportion of these pools are seem to be close to each other for the years of 1997, 2007 and 2017. Nevertheless, living tree biomass including
$A G B$ and $B G B$ has the highest rate in 2017 when compared with 1997 and 2007. This is due to the increase of growing stock of forest trees from 1997 to 2017 in the study area. 


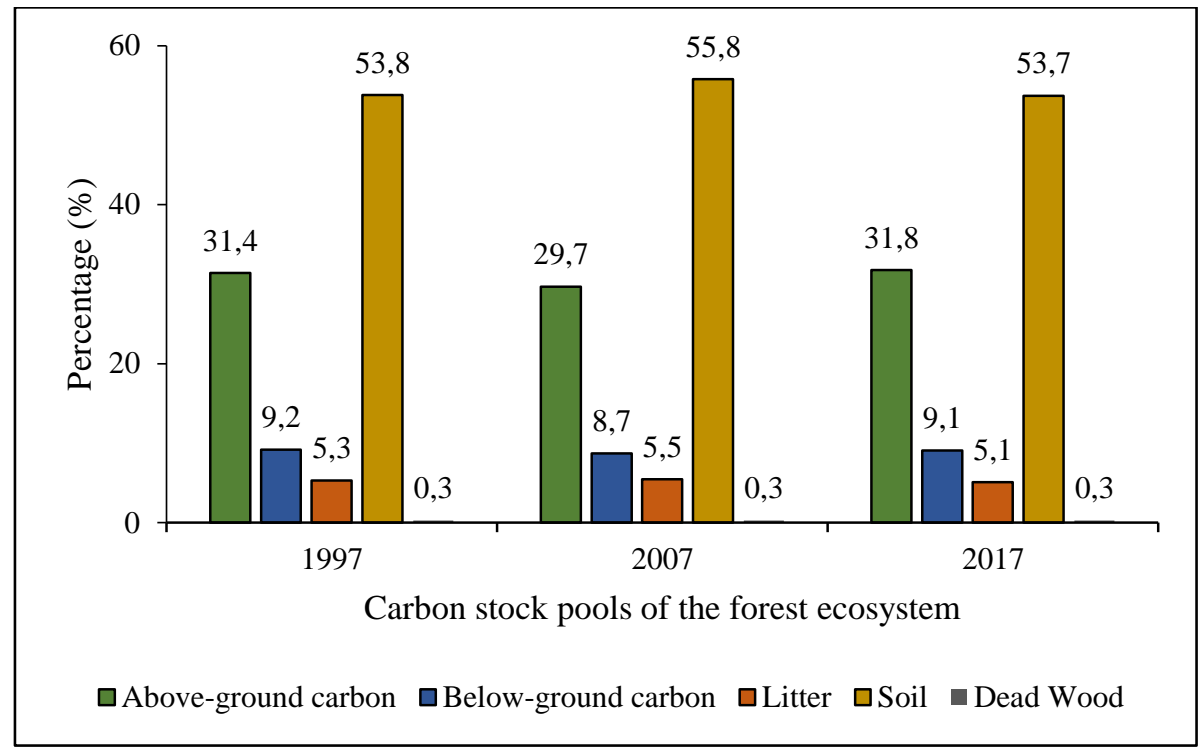

Figure 3. Carbon density changes of the study area

It's investigated that ratios of the productive forests in total forest area have continuously increased during two decades. While $75.7 \%$ of the total forest areas were productive in 1997, this ratio reached the $82.1 \%$ in 2007 and $87.6 \%$ in 2017. In parallel with land use and forest productivity changes by years, carbon stock densities $(\mathrm{Mg} / \mathrm{ha})$ of the study area, as matter of course, has changed. Figure 4 and Figure 5 demonstrates the change of carbon stock densities in the study

area.

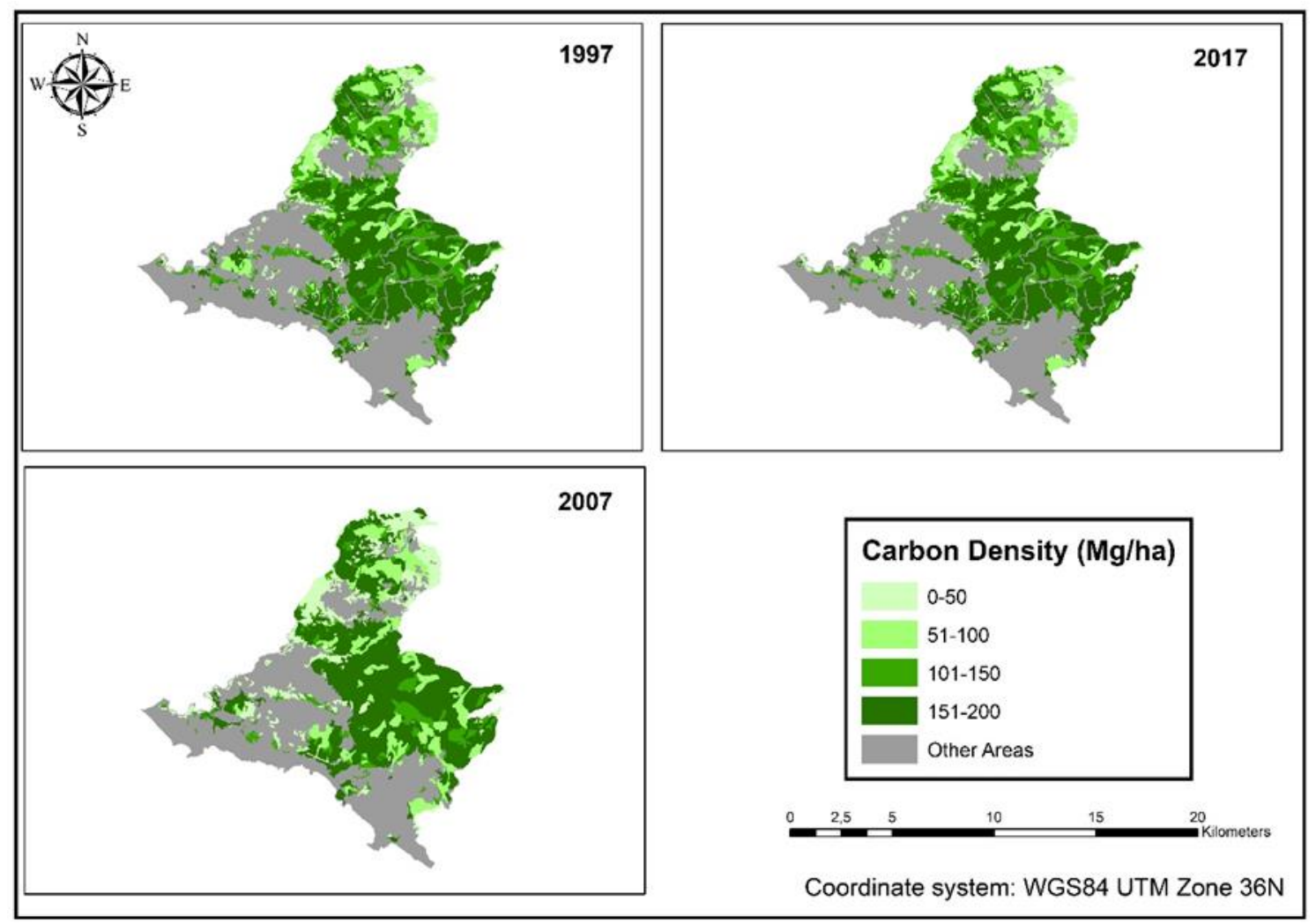

Figure 4. Changes of carbon stock density of the study area 


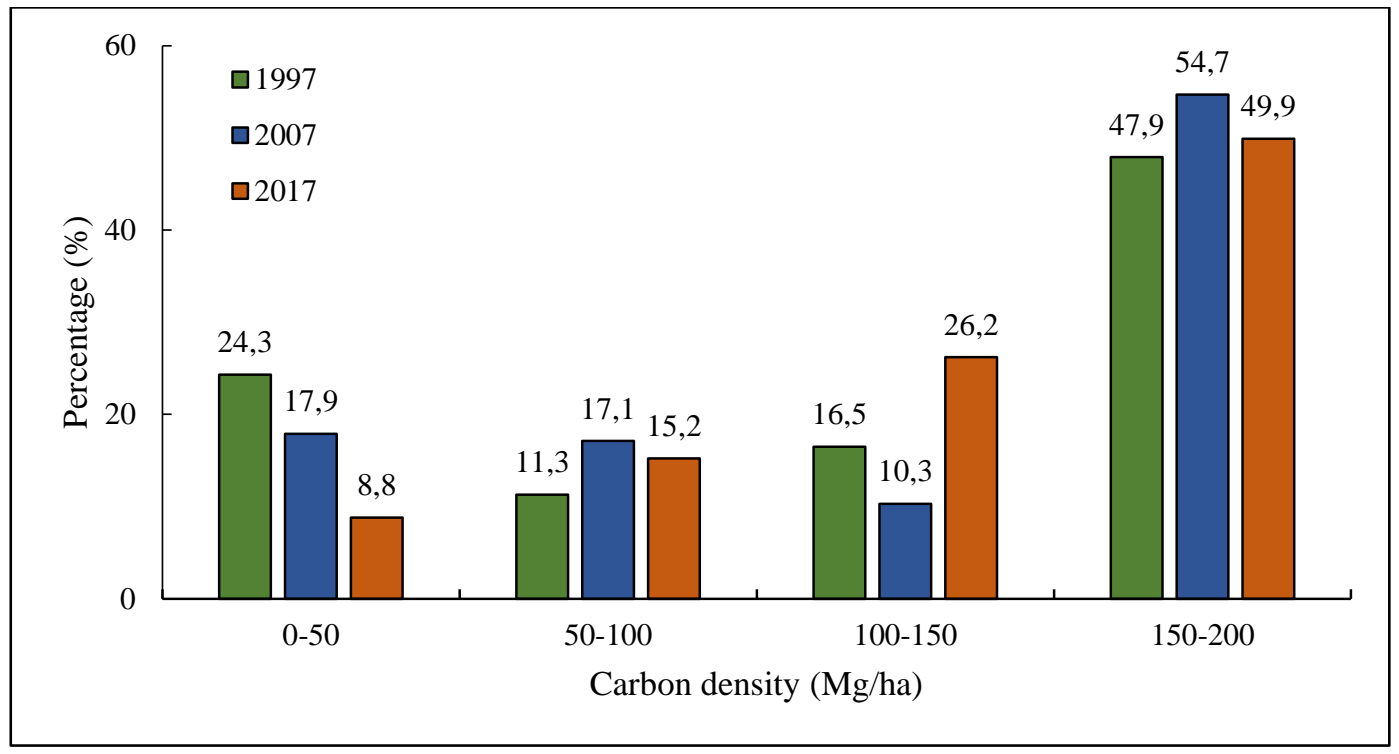

Figure 5. Distribution of carbon density groups in total forest area

\section{Discussion}

Total carbon stock of the forest ecosystem in the study unit (Alara FPU) increased by 12.7\% from 1997 to 2017. Despite the reduction of total forest area for this period (from 7497 ha to 7344 ha), carbon stocks of all biomass pools (living tree, litter, soil and dead wood) in forest ecosystem raised with the increase of productive forest lands and growing stock. From this point, it can be concluded that improvement of forest quality, in addition to quantity, lead to more sequestration of carbon in the forest ecosystem.

Despite using different coefficients and handling different units, various studies in
Turkey have reported that carbon stocks of forests have upward trend over time (Table 6). The main reasons of this trend can be explained as increase of the forest area, quality and growing stock. In more detail, the main factors affecting carbon storage and sequestration can be explained as follows: changing forest management strategies, increase of protected forest areas, rehabilitation of degraded forest lands, afforestation and reforestation activities, land use change, migration from forest villages to the town and increase in the public awareness of the forest ecosystem.

Table 6. Some studies on carbon stock changes across Turkey

\begin{tabular}{ccccc}
\hline \multirow{2}{*}{ Study } & $\begin{array}{c}\text { Study Area } \\
\text { (unit) }\end{array}$ & period & Carbon stock pools & $\begin{array}{c}\text { Change } \\
\text { (approx.\%) }\end{array}$ \\
\hline Asan (1995) & Turkey & $1960-1995$ & AGB & +13.3 \\
\hline Sivrikaya et al. (2007) & Artvin FPU & $1972-2002$ & Living tree biomass & +42.2 \\
\cline { 2 - 5 } & Camili FPU & $1984-2005$ & Living tree biomass & +1.6 \\
\hline Yolası̆ğmaz \& Keleş (2009) & Balci FPU & $1984-2006$ & Living tree biomass & +17.6 \\
\hline Sivrikaya \& Bozali (2012) & Türkoğlu FPU & $1991-2002$ & Living tree biomass & +19.5 \\
\hline Bulut (2012) & Saraycık FPU & $1970-2009$ & Forest ecosystem & +90.7 \\
\hline
\end{tabular}


Table 6. (Continued)

\begin{tabular}{ccccc}
\hline $\begin{array}{c}\text { Kadığulları \& Karahalil } \\
\text { (2013) }\end{array}$ & $\begin{array}{c}\text { Köprülü } \\
\text { Canyon } \\
\text { National Park }\end{array}$ & 1965-2008 & Forest ecosystem & +11.0 \\
\hline Sivrikaya et al. (2013) & Hartlap FPU & $1991-2002$ & Living tree biomass & +9.6 \\
\hline Değermenci \& Zengin (2016) & Daday FPU & $1970-2012$ & Forest ecosystem & +113.7 \\
\hline Durkaya et al. (2017) & Sarılan FPU & $1986-2005$ & Forest ecosystem & +15.5 \\
\hline Seki et al. (2017) & Taşköprü FE & $1989-2009$ & Forest ecosystem & +37.4 \\
\hline Günlü et al. (2019) & $\begin{array}{c}\text { Upstream of } \\
\text { the Göksu } \\
\text { River Basin }\end{array}$ & $1993-2015$ & AGB & +53.8 \\
\hline
\end{tabular}

Note: Living tree biomass includes above- and below-ground biomass; forest ecosystem includes total living tree, litter, soil and dead wood biomass.

In this study and also previous ones, the effects of land use change, silvicultural treatments, and forest management policies on forest carbon stocks have been underlined. Relationship between these effects and the carbon stock change should be investigated with more studies on this subject. Because, to maintain or increase the carbon stock in the forest ecosystems is essential in terms of carbon management.

For higher accuracy in estimation of carbon stock in the forest ecosystems, quantity of the studies on carbon stock in above- and below-ground living tree biomass, and especially in litter, soil and dead wood must be increased (Tolunay, 2011). Besides, there is a great regional diversity which causes the different forest dynamics in Turkey. Growth, and thereby biomass and carbon stock rates of the forest ecosystem are directly affected from this regional difference. Therefore, studies on biomass and carbon stock of natural sources should be investigated at the regional or local scale to obtain more stable estimates (Sakici et al., 2018).

Another important point relevant to the carbon stock monitoring is to establish permanent sample plot design in Turkey. Unfortunately, studies on the determination of carbon stock and it's change over time have been conducted based on temporary sample plots in the country, because of the absence of permanent sample plots.
This type of data leads to higher biases and lower accuracy on carbon stock estimates. To avoid these inconveniences, there is an urgent need for permanent sample plots for each species, and each region in Turkey.

\section{Acknowledgements}

The authors wish to thank Forest Management and Planning Department for data supply.

\section{Ethics Committee Approval N/A}

\section{Peer-review}

Externally peer-reviewed.

\section{Author Contributions}

Conceptualization: M.S., $\quad$ D.A.; Investigation: M.S; Material and Methodology: M.S., D.A.; Supervision: M.S.; Visualization: M.S., D.A.; WritingOriginal Draft: M.S.; Writing-review \& Editing: M.S.; Other: All authors have read and agreed to the published version of manuscript.

\section{Conflict of Interest}

The authors have no conflicts of interest to declare.

\section{Funding}

The authors declared that this study has received no financial support. 


\section{References}

Asan, Ü. (1995). Global iklim değişimi ve Türkiye ormanlarında karbon birikimi. Istanbul University Journal of the Faculty of Forestry, 45(1-2), 23-38.

Bulut, A. (2012). Carbon Stock Change Between 1970 And 2009 In Mixed Fir Forests (A Case Study-Saraycik Forest Management Chiefdom). Kastamonu University Journal of Forestry Faculty, 12(31), 203-207.

Değermenci, A. S. \& Zengin, H. (2016). Ormanlardaki karbon birikiminin konumsal ve zamansal değişiminin incelenmesi: Daday planlama birimi örneği. Artvin Çoruh Üniversitesi Orman Fakültesi Dergisi, 17(2), 177-187.

Dixon, R. K., Solomon, A. M., Brown, S., Houghton, R. A., Trexier, M. C. \& Wisniewski, J. (1994). Carbon pools and flux of global forest ecosystems. Science, 263(5144), 185-190.

Durkaya, B., Durkaya, A. \& Kocaman, M. (2017). Karbon stok değişimi; Bolu Sarılan işletme şefliği. Bartın Orman Fakültesi Dergisi, 19(1), 268-275.

ESRI (2021). ArcMap 10.6 Software. Available at:

https://desktop.arcgis.com/en/arcmap/10.6/get -started/setup/arcgis-desktop-systemrequirements.htm

FRA. (2010). Global forest resources assessment 2010, Country Report; Turkey. Rome.

GDF. (1997). Forest management plan of Alara planning unit. General Directorate of Forestry of Turkey, Ankara.

GDF. (2007). Functional forest management plan of Alara planning unit. General Directorate of Forestry of Turkey, Ankara.

GDF. (2017a). Ecosystem-based functional forest management plan of Alara planning unit. General Directorate of Forestry of Turkey, Ankara.

GDF. (2017b). Ekosistem tabanlı fonksiyonel orman amenajman planlarının düzenlenmesine ait usul ve esaslar. General Directorate of Forestry of Turkey, Ankara.

Günlü, A., Göl, C. \& Sarıçam, F. (2019). Topraküstü meşcere karbonunun zamansal ve konumsal değişiminin değerlendirilmesi: Yukarı Göksu Nehri Havzası örneği. Türkiye Ormancilık Dergisi, 20(4), 352-359.

IPCC (Intergovernmental Panel on Climate Change). (2003). Good practice guidance for land use, land-use change and forestry (Eds. J Penman, M Gytarsky, T Hiraishi, T Krug, D Kruger, R Pipatti, L Buendia, K Miwa, T Ngara, K Tanabe, F Wagner). IPCC/OECD/IEA/IGES, Hayama, Japan.
Retrieved 5 September 2009 from

http://www.ipcc-

nggip.iges.or.jp/public/gpglulucf/gpglulucf_co ntents.html.

IPCC (Intergovernmental Panel on Climate Change). (2006). IPCC Guidelines for National Greenhouse Gas Inventories, Prepared by the National Greenhouse Gas Inventories Programme (Eds. HS Eggleston, L Buendia, K Miwa, T Ngara, K Tanabe). IGES, Japan. Retrieved 5 September 2009 from http://www.ipccnggip.iges.or.jp/public/2006gl /index.html.

IPCC (Intergovernmental Panel on Climate Change). (2018). Global warming of $1.5^{\circ} \mathrm{C}$, an IPCC special report on the impacts of global warming of $1.5^{\circ} \mathrm{C}$ above pre-industrial levels and related global greenhouse gas emission pathways, in the context of strengthening the global response to the threat of climate change, sustainable development, and efforts to eradicate poverty. World Meteorological Organization, Geneva, Switzerland.

Kadıŏulları, A. İ. \& Karahalil, U. (2013). Spatiotemporal change of carbon storage in forest biomass: A case study in Köprülü Canyon National Park. Journal of Forestry Faculty of Kastamonu University, 13(1), 1-14.

Sakici, O. E., Seki, M. \& Saglam, F. (2018). Above-ground biomass and carbon stock equations for crimean pine stands in Kastamonu region of Turkey. Fresenius Environmental Bulletin, 27(10), 7079-7089.

Saxe, H., Cannell, M. G., Johnsen, Ø., Ryan, M. G. \& Vourlitis, G. (2001). Tree and forest functioning in response to global warming. New Phytologist, 149(3), 369-399.

Seki, M., Sakıcı, O. E., Büyükterzi, M. \& Sağlam, F. (2017). Temporal changes in carbon stock of Taşköprü Enterprise Forests. International Taşköprü Pompeiopolis Science Cultural Arts Research Symposium, 10-12 April, Taşköprü, Kastamonu, 1564-1577.

Sivrikaya, F., Keleş, S. \& Çakir, G. (2007). Spatial distribution and temporal change of carbon storage in timber biomass of two different forest management units. Environmental Monitoring and Assessment, 132(1-3), 429-438.

Sivrikaya, F. \& Bozali, N. (2012). Karbon Depolama Kapasitesinin Belirlenmesi: Türkoğlu Planlama Birimi Örneği. Bartın Orman Fakültesi Dergisi, 14 (1.Special Issue), 69-76.

Sivrikaya, F., Baskent, E. Z. \& Bozali, N. (2013). Spatial dynamics of carbon storage: a case study from Turkey. Environmental 
Monitoring and Assessment, 185(11), 94039412.

Socha, J. (2008). Effect of topography and geology on the site index of Picea abies in the West Carpathian, Poland. Scandinavian Journal of Forest Research, 23(3), 203-213.

Tolunay, D. \& Çömez, A. (2008). Amounts of organic carbon stored in forest floor and soil in Turkey. In National Symposium on Air Pollution and Control. Proceedings Books, Hatay, 750-765.

Tolunay, D. (2011). Total carbon stocks and carbon accumulation in living tree biomass in forest ecosystems of Turkey. Turkish Journal of Agriculture and Forestry, 35(3), 265-279.

Tolunay, D. (2013). Türkiye'de artım ve ağaç servetinden bitkisel kütle ve karbon miktarlarının hesaplanmasında kullanılabilecek katsayılar. Ormancilıkta Sektörel Planlamanın 50. Y1lı Uluslararası Sempozyumu Bildiriler Kitab1, 26-28 Kasım 2013 Antalya, 240-251.

Vogt, K. (1991). Carbon budgets of temperate forest ecosystems. Tree Physiology, 9(1-2), 69-86.

Yolasığmaz, H. A. \& Keleş, S. (2009). Changes in carbon storage and oxygen production in forest timber biomass of Balci forest management unit in Turkey between 1984 and 2006. African Journal of Biotechnology, 8(19), 4872-4883. 